\title{
STUDY OF THE ASSOCIATION OF THE NUTRITIONAL PROFILE OF PREGNANT WOMEN WITH THE BIRTH WEIGHT OF NEWBORNS IN MOROCCO
}

\author{
Houda Elfane ${ }^{l}$, Sanaa El-Jamal, Khadija Sahel ${ }^{1}$, Mohamed Mziwira ${ }^{2}$, Mohammed El Ayachi', Rekia Belahsen ${ }^{l}$
}

${ }^{1}$ Laboratory of Biotechnology, Biochemistry and Nutrition. Training and Research Unit on Nutrition and Food Sciences. Department of Biology, Faculty of Sciences, Chouaib Doukkali University, El Jadida, 24000 Morocco

${ }^{2}$ École Normal Supérieure, Hassan II University, Casablanca, Morocco

\begin{abstract}
Background. Low birth weight (LBW) is an important predictor of neonatal morbidity and mortality. It reflects the nutritional status of the mother and the quality of health care services during pregnancy.

Objective. The objective of this study is to determine the factors associated with low birth weight of children born to Moroccan pregnant women in the province of El Jadida.

Material and Methods. This cross-sectional case-control study was carried out in the maternity ward of El Jadida provincial hospital on 344 parturient women, half of whom had given birth to children with an LBW and the other half of children with normal weight (NW) at birth. Information on maternal gestational and socioeconomic characteristics as well as eating habits was collected using a questionnaire and anthropometric measurements were taken on the newborns. Results. The study identified 172 parturient who gave birth to newborns with LBW and 172 parturient who gave birth to newborns of NW. The proportions of LBW are greater in first-time mothers $(50.6 \%)$ and professionally inactive $(86.6 \%)$. The mean weight of LBW newborns is $2013.95 \pm 372.95 \mathrm{~g}$ compared to $3380 \pm 217.59 \mathrm{~g}$ for NW newborns. The determined factors associated with LBW are the low socio-economic level $(\mathrm{OR}=3.18 ; 95 \% \mathrm{CI}$ : 1.09-9.23), insufficient monitoring of prenatal consultation $(\mathrm{OR}=2.91 ; 95 \% \mathrm{CI}: 1,71-4.95)$, origin from rural areas $(\mathrm{OR}=0.52 ; 95 \% \mathrm{CI}$ : $0.30-0.91)$ and lack of nutritional education ( $\mathrm{OR}=0.17 ; 95 \% \mathrm{CI}: 0,09-0.34)$. The daily calcium intake in mothers of newborns with LBW is $33.82 \%$ of the recommended daily allowance (RDA), the daily iron requirement coverage was $50 \%$, folates $66,16 \%$ and zinc $87.72 \%$ of the RDA.

Conclusions. Well-targeted and coordinated education and awareness-raising actions on early pregnancy and feeding pregnant women could have a positive impact on improving the birth rate of children with a weight deficit.
\end{abstract}

Key words: pregnant woman, low birth weight, risk factors, newborns, anthropometric measurements, nutritional status

\section{INTRODUCTION}

Low birth weight (LBW) is a major public health problem, leading to higher perinatal morbidity and mortality, in both developed and developing countries [27]. LBW includes both preterm births ( $<37$ full weeks of gestation) and term newborns with intrauterine growth retardation, but it remains an important indicator of perinatal health due to its association with survival, health status and development of the newborn [13]. In addition, the intrauterine nutritional environment is an important determinant of the state of health and subsequent growth of an individual. Pregnant women with poor nutritional status, living in difficult conditions and receiving poor nutrition, are more likely to give birth to low birth weight children [21]. According to the World Health Organization (WHO), there are some 20 million newborns with LBW every year [26], the causes and consequences of LBW are often complex and play an important role in the life cycle of the individual. This leads to significant consequences for companies, in terms of very costly support and in terms of losses in human capital and economic productivity [14]. In 2012, the World Health Assembly (WHA) approved a Comprehensive Implementation Plan on Maternal, Child and Young Child Nutrition, which includes six global nutrition goals. One of these goals is the ambitious 30\% reduction in the prevalence of PNH between 2012 and 2025 [26]. Morocco, however, recorded a rate of $17.3 \%$ of births

Corresponding author: Rekia Belahsen, Laboratory of Biotechnology, Biochemistry and Nutrition. Training and Research Unit on Nutrition and Food Sciences, Chouaib Doukkali University, School of Sciences, El Jadida, 24000 Morocco, Phone: 21252334 2325/212 6649716 16, Fax: 2125233421 87/4449, e-mail: b.rekia@gmail.com or rbelahsen@yahoo.com

(C) Copyright by the National Institute of Public Health NIH - National Research Institute 
with a low weight in 2015. This rate placed Morocco in fourth place among African countries recorded with a high rate of births with a low weight [3]. In fact, anthropometric measurements of the newborn are fairly reliable indicators of the mother's state of health and nutritional status before and during pregnancy. They are influenced by geographic, genetic, racial and nutritional factors [6].

The objective of this study is therefore to study certain maternal and socioeconomic risk factors associated with LBW and the relationship between the nutritional status of pregnant women and the weight of newborns at birth.

\section{MATERIAL AND METHOD}

The study took place at the maternity ward of the El Jadida provincial hospital over a period from January 1 to December 31, 2018. This hospital represents a 2nd level public health structure with a high influx of the rural population.

\section{Sample}

This is a cross-sectional case-control study that was carried out at the time of delivery, with 172 mothers and their normal weight (NW) infants and 172 mothers with infants with LBW. A normal weight child (NW) is defined as any newborn whose birth weight is between 2,500 and 4,000 grams. A low birth weight child (LBW) is defined as any newborn whose birth weight is less than $2500 \mathrm{~g}$ regardless of the term of pregnancy.

\section{Inclusion and exclusion criteria}

All children born alive and their mothers are included in this study. Stillbirths and fetal deaths in utero are excluded from the study.

\section{Information collected}

The information was collected using an established questionnaire, making it possible to collect data on socio-demographic and gestational factors. Another semi-quantitative food frequency questionnaire was also completed with the participants in this study to transcribe the food consumption habits of the sample studied. The frequency of food consumption was reported per day, week or month and the portion size consumed by women was estimated. Daily intake is calculated by multiplying the relative frequency of consumption of each food by the nutrient content, standard serving size and amount of serving taken by each woman, obtained from the program Bilnut, version (2.01) [23].

\section{Collection of anthropometric data at childbirth}

In mothers, the weight is measured in kilograms, before childbirth, using a scale in a standing position, motionless, without support, wearing only underwear. The mother's height was measured using an adult measuring board, graduated in centimeters with the feet together, the arms hanging alongside the body, the knees well extended, the back, the buttocks and the heels applied against the vertical upright of the board.

The body mass index (BMI) was calculated by dividing the weight in kilograms by the square of the height in meters [28]. In newborns, data collection on weight, height, headcircumference, armcircumference, thoracic perimeter and sex is collected within the first two hours after childbirth. The newborn's weight is measured to the nearest $10 \mathrm{~g}$ using a SECA ${ }^{\circledR}$ brand baby scale. The height is measured using a measuring rod graduated in centimeters with the naked newborn flat on his back, the head firmly held against the fixed headrest board and the thighs and knees extended by the interviewer. Head circumference is measured at its greatest diameter. The thoracic perimeter is measured at the level of the nipples and the arm circumference on the left arm midway between the acromion and the olecranon. All these measurements were taken in centimeters using an inextensible tape measure.

The Ponderal index (PI) is arrived at by the following formula:

PI $=$ birth weight $\times 100 /(\text { Crown heal length })^{3}[8]$.

\section{The Apgar score}

The Apgar score is used to measure the state of the vital functions of a newborn baby, the elements that include it are: skin color, heart rate, reflexes, muscle tone and breathing. This Apgar score is designed to assess signs of hemodynamic compromise such as cyanosis, hypo perfusion, bradycardia, hypotonia, respiratory depression or apnea. Each element is scored 0,1 or 2 depending on the conditions observed, then the results are then added together to give a score out of 10 . The maximum score is 10 points, equivalent to the best possible health condition. The Apgar score is normal if it is $\geq 7$ at 1 minute and 5 minutes after the infant is born. A score $<7$ and a fortiori less than 3 should lead to appropriate management requiring neonatal intensive care [16].

\section{Statistical analyses}

Statistical analyses are performed using SPSS software (Statistical Package for the Social Sciences) version 23. A bivariate analysis was performed using Pearson's Chi-square test to separately study the independent variables associated with the dependent variable (LBW). The percentages of low birth weight were compared in the different modalities of the independent variables collected. Comparisons 
between two groups were made using Student's test. Comparisons between three or more groups were made using an ANOVA followed by a Tukey test to determine the differences between the groups. Correlations between two continuous variables were determined by calculating the Pearson coefficient (r). The probability threshold $\mathrm{p} \leq 0.05$ was retained as statistically significant.

\section{Ethical considerations}

The investigation obtained the approval of the regional directorate of the Moroccan Ministry of Health in greater Casablanca. Participation in the survey was subject to the free and informed consent of the persons selected. After receiving a detailed explanation of the survey process and conditions, the female respondents were free to decline or withdraw from the survey at any time.

\section{RESULTS}

Table 1 illustrates the distribution of birth weight according to the characteristics of the mother and the newborn. The mean age of mothers of newborns with LBW is $26.02 \pm 5.48$ and that of mothers of normal weight newborns is $24.86 \pm 5.34$. The proportion of LBW children is greater among first-time mothers $(50.6 \%)$, illiterates $(59.9 \%)$ and among professionally inactive women $(86.6 \%)$.

The results of the risk factor analysis, using a binary logistic regression model, provide information on a significant association of low birth weight with low socioeconomic status $(\mathrm{OR}=3.18 ; 95 \% \mathrm{CI}$ : 1.09- 9.23), insufficient of prenatal consultation monitoring $(\mathrm{OR}=$ 2.91; 95\% CI: 1.71-4.95), origin from rural areas (OR $=0.52 ; 95 \% \mathrm{CI}: 0.30-0,91)$ and lack of nutritional education ( $\mathrm{OR}=0.17$; 95\% CI: 0.09-0.34). Table 1 also shows that newborns with LBW are 0.37 more likely

Table 1. Socio-demographic characteristics of the study population

\begin{tabular}{|c|c|c|c|c|c|c|c|}
\hline \multirow[t]{2}{*}{$\begin{array}{l}\text { Socio-demographic } \\
\text { characteristics }\end{array}$} & & \multicolumn{2}{|c|}{$\begin{array}{c}\text { Newborn } \\
\text { low birth weight } \\
\text { (LBW) }\end{array}$} & \multicolumn{2}{|c|}{$\begin{array}{c}\text { Newborn } \\
\text { normal weight } \\
(\mathrm{NW})\end{array}$} & \multirow[t]{2}{*}{$P$} & \multirow[t]{2}{*}{$\begin{array}{c}\text { Adjusted OR } \\
{[95 \% \mathrm{CI}]}\end{array}$} \\
\hline & & $\mathrm{N}$ & $\%$ & $\mathrm{~N}$ & $\%$ & & \\
\hline Age & $\begin{array}{c}<20 \\
\geq 20 ; 30 \geq \\
>30\end{array}$ & $\begin{array}{c}28 \\
108 \\
36\end{array}$ & $\begin{array}{l}16.3 \\
62.8 \\
20.9\end{array}$ & $\begin{array}{c}22 \\
123 \\
27\end{array}$ & $\begin{array}{l}12.8 \\
71.5 \\
15.7\end{array}$ & NS & - \\
\hline Origin & $\begin{array}{l}\text { Urban } \\
\text { Rural }\end{array}$ & $\begin{array}{c}25 \\
147 \\
\end{array}$ & $\begin{array}{l}14.5 \\
85.5 \\
\end{array}$ & $\begin{array}{c}42 \\
130 \\
\end{array}$ & $\begin{array}{l}24.4 \\
75.6 \\
\end{array}$ & 0.022 & $0.526[0.304-0.911]$ \\
\hline Socioeconomic level & $\begin{array}{c}\text { Weak } \\
\text { Average } \\
\text { Raised }\end{array}$ & $\begin{array}{c}125 \\
42 \\
5\end{array}$ & $\begin{array}{c}72.7 \\
24.4 \\
2.9 \\
\end{array}$ & $\begin{array}{l}102 \\
57 \\
13\end{array}$ & $\begin{array}{c}59.3 \\
33.1 \\
7.6 \\
\end{array}$ & 0.020 & 3.18 [1.09-9.23] \\
\hline Study level & $\begin{array}{c}\text { Illiterate } \\
\text { Primary } \\
\text { Middle School } \\
\text { High school } \\
\text { University } \\
\end{array}$ & $\begin{array}{c}103 \\
42 \\
24 \\
3 \\
-\end{array}$ & $\begin{array}{c}59.9 \\
24.4 \\
14 \\
1.7 \\
- \\
\end{array}$ & $\begin{array}{c}82 \\
47 \\
31 \\
9 \\
3 \\
\end{array}$ & \begin{tabular}{c|}
47.7 \\
27.3 \\
18 \\
5.2 \\
1.7 \\
\end{tabular} & NS & - \\
\hline Profession & $\begin{array}{l}\text { Without } \\
\text { Worker } \\
\text { Employee }\end{array}$ & $\begin{array}{c}149 \\
23 \\
-\end{array}$ & $\begin{array}{c}86.6 \\
13.4 \\
-\end{array}$ & $\begin{array}{c}156 \\
14 \\
2\end{array}$ & $\begin{array}{c}90.7 \\
8.1 \\
1.2\end{array}$ & NS & - \\
\hline Parity & $\begin{array}{l}\text { Primiparous } \\
\text { Multiparous }\end{array}$ & $\begin{array}{l}87 \\
85\end{array}$ & $\begin{array}{l}50.6 \\
49.4\end{array}$ & $\begin{array}{l}97 \\
75\end{array}$ & $\begin{array}{l}56.4 \\
43.6\end{array}$ & NS & - \\
\hline Prenatal consultation & $\begin{array}{l}<4 \text { consultations } \\
>4 \text { consultations }\end{array}$ & $\begin{array}{c}115 \\
57\end{array}$ & $\begin{array}{l}66.9 \\
33.1 \\
\end{array}$ & $\begin{array}{l}147 \\
25\end{array}$ & $\begin{array}{l}85.5 \\
14.5 \\
\end{array}$ & 0.000 & 2.91 [1.71-4.95] \\
\hline Nutrition education & $\begin{array}{l}\text { Yes } \\
\text { No }\end{array}$ & $\begin{array}{c}13 \\
159 \\
\end{array}$ & $\begin{array}{c}7.6 \\
92.4\end{array}$ & $\begin{array}{c}54 \\
118 \\
\end{array}$ & $\begin{array}{l}31.4 \\
68.6 \\
\end{array}$ & 0.000 & $0.17[0.09-0.34]$ \\
\hline Pregnancy outcome & & & & & & & \\
\hline Mode of delivery & $\begin{array}{l}\text { Low way } \\
\text { Cesarean }\end{array}$ & $\begin{array}{c}139 \\
33 \\
\end{array}$ & $\begin{array}{l}80.81 \\
19.18 \\
\end{array}$ & $\begin{array}{c}158 \\
14 \\
\end{array}$ & $\begin{array}{c}91.86 \\
8.13 \\
\end{array}$ & 0.004 & 0.37 [0.19-0.72] \\
\hline $\begin{array}{l}\text { Score of Apgar at } 5 \mathrm{~min} \\
\text { of life }\end{array}$ & $\begin{array}{r}<7 \\
\geq 7 \\
\end{array}$ & $\begin{array}{l}94 \\
78 \\
\end{array}$ & $\begin{array}{l}54.65 \\
45.34 \\
\end{array}$ & $\begin{array}{c}5 \\
167 \\
\end{array}$ & $\begin{array}{c}2.90 \\
97.09\end{array}$ & 0.000 & 40.25 [15.74-102.92] \\
\hline Neonatal intensive care & $\begin{array}{l}\text { Yes } \\
\text { No }\end{array}$ & $\begin{array}{c}121 \\
51\end{array}$ & $\begin{array}{l}70.34 \\
29.65\end{array}$ & $\begin{array}{c}4 \\
168\end{array}$ & $\begin{array}{l}2.32 \\
97.67\end{array}$ & 0.000 & 99.64 [35.07-283.10] \\
\hline
\end{tabular}

$\mathrm{CI}=$ Confidence Interval, OD: Odds ratio, NS = Not Significant, LBW: Low Birth Weight, NW: Normal Weigh 
to deliver vaginally. The use of the Apgar score, which provides information on the quality of newborns at the 5th minute of their birth, shows that the prevalence of LBW is very high in newborns with an Apgar score $<7$ at the 5 th minute of birth life $(\mathrm{OR}=40.25 ; 95 \% \mathrm{CI}$ : 15.74-102.92).

Table 2 reports the anthropometric characteristics of newborns with LBW and those at normal weight. The results concerning these anthropometric parameters in newborns of LBW which appear to be much lower than those of newborns of normal weight. The distribution of newborns with LBW according to sex shows a female predominance $(60.64 \%)$ with all measurements statistically higher than for boys.

Table 3 shows the relationships between maternal age, weight, height and body mass index (BMI) and anthropometric parameters of the newborn. It

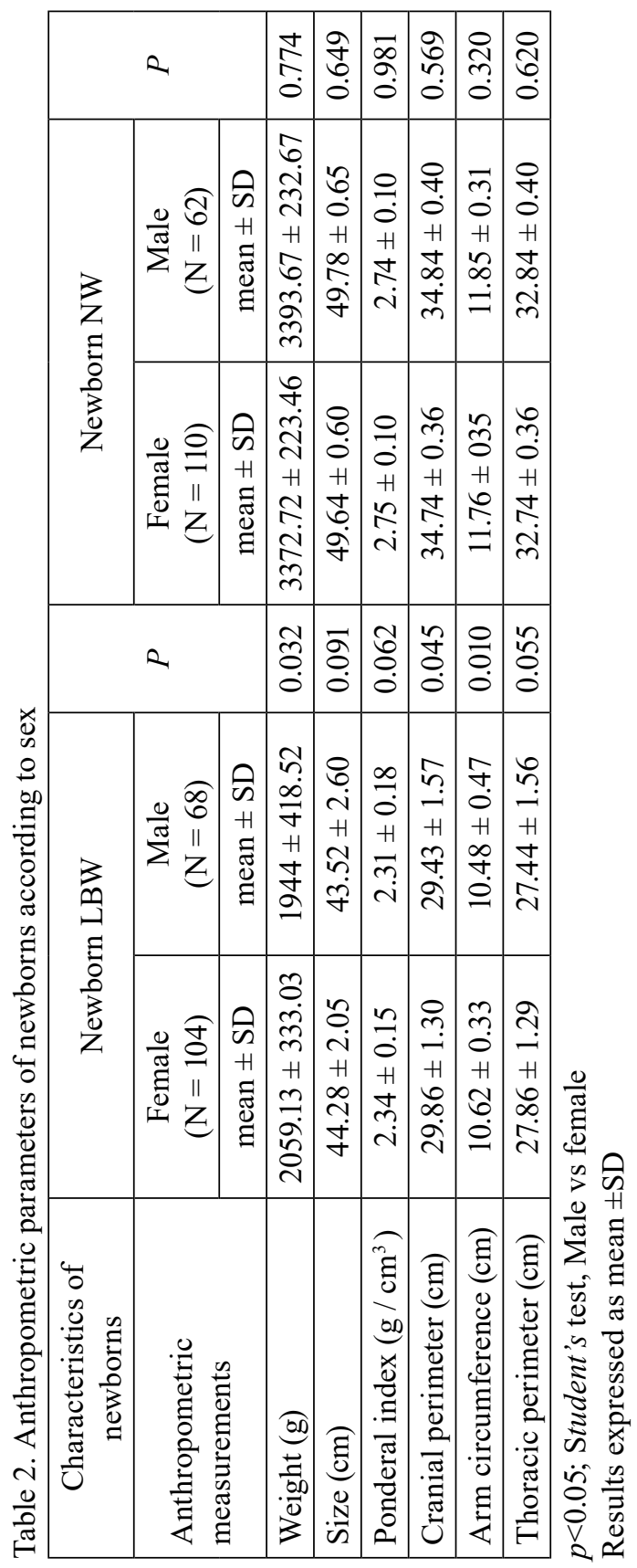

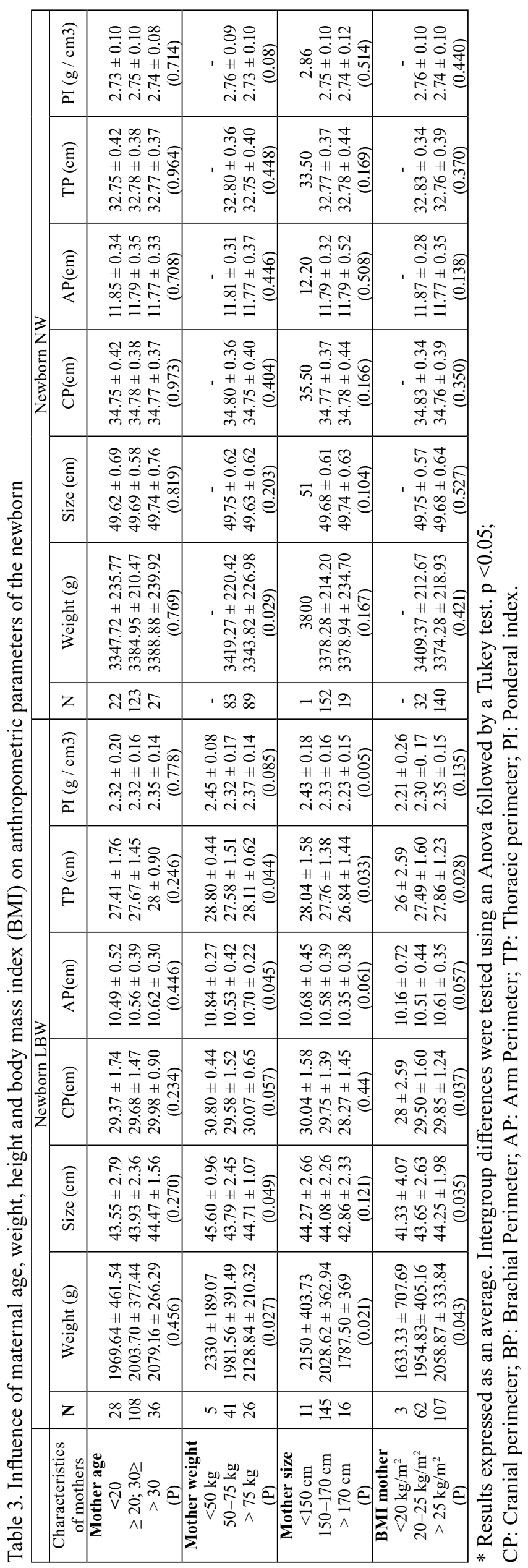


appears that with the exception of maternal age, the weight, height and body mass index of the mother are significantly correlated with all the anthropometric parameters of newborns with LBW. As for newborns of normal weight, only the mother's weight was correlated with the child's weight.

Table 4 shows the average daily intake for each of the eight food groups. High consumption was observed for all food groups in mothers of NW newborns compared to mothers of LBW children except for the legume group. The analysis of the different types of food consumed per day shows a high consumption of cereals which is significantly correlated with the weight of newborns $(\mathrm{P}=0.035)$ and a low consumption of the groups of meats and derivatives, eggs, products dairy and vegetables compared to the female group of NW newborns.

The approximate averages of the daily energy and nutrient intakes, relative to the recommendations (RDA) for all women are shown in Table 5. On average, nutritional intakes exceed the recommended daily values for all groups of newborn mothers with respective rates of $(108.84 \%$ vs $124.72 \%)$ for energy), $(133.52 \%$ vs $152.39 \%)$ for proteins, $(104.70 \%$ vs $137.64 \%)$ for vitamin $C$ and $(139.14 \%$ vs $144.85 \%)$ for magnesium intakes in mothers of newborns with LBW and newborns with NW respectively. However, except for zinc $(87.72 \%$ vs $100.18 \%)$ which covers the recommended daily allowance for mothers of newborns of normal weight, insufficient iron intakes $(52.37 \%$ vs $70.77 \%)$, folates $(66.16 \%$ vs $72.66 \%)$ and calcium $(33.82 \%$ vs. $60.23 \%)$ are recorded in the two groups of mothers of children LBW and NW respectively.

\section{DISCUSSION}

The results of the present study reveal that the determinants of LBW are multiple and intricate. The data reported here show that a high proportion $(62.8 \%)$ of underweight newborns is among mothers aged 20 to 30 years. However, there is no significant association between maternal age and LBW. This result is consistent with those found by some authors

Table 4. Pearson's correlation for food groups consumed / day by mothers and weight of LBW newborns and NW newborns

\begin{tabular}{|l|c|c|c|c|}
\hline \multicolumn{1}{|c|}{ Food groups } & $\begin{array}{c}\text { Mothers of LBW } \\
\text { newborns }\end{array}$ & $P$ & $\begin{array}{c}\text { Mothers of NW } \\
\text { newborns }\end{array}$ & $P$ \\
\hline Cereals $\left(\right.$ g day $\left.^{-1}\right)$ & $488.83 \pm 112$ & 0.651 & $534.07 \pm 106.55$ & 0.035 \\
\hline Meat and derivatives $\left(\mathrm{g} \mathrm{day}^{-1}\right)$ & $68.53 \pm 26.25$ & 0.024 & $86.95 \pm 43.19$ & 0.097 \\
\hline Dairy products $\left(\mathrm{g} \mathrm{day}^{-1}\right)$ & $77.42 \pm 45.58$ & 0.032 & $134.12 \pm 58.39$ & 0.197 \\
\hline Fish $\left(\mathrm{g} \mathrm{day}^{-1}\right)$ & $31.73 \pm 17.60$ & 0.611 & $51.40 \pm 27.32$ & 0.687 \\
\hline Eggs $\left(\right.$ g day $\left.^{-1}\right)$ & $25.05 \pm 16.71$ & 0.039 & $34.43 \pm 21.68$ & 0.146 \\
\hline Fruits $\left(\right.$ g day $\left.^{-1}\right)$ & $168.61 \pm 62.94$ & 0.676 & $229.61 \pm 112.85$ & 0.834 \\
\hline Vegetables $\left(\right.$ g day $\left.^{-1}\right)$ & $271.96 \pm 66.41$ & 0.041 & $359 \pm 92.90$ & 0.167 \\
\hline Legume $\left(\right.$ g day $\left.^{-1}\right)$ & $28.21 \pm 11.77$ & 0.295 & $30.55 \pm 25.41$ & 0.463 \\
\hline
\end{tabular}

LBW: low birth weight ; NW: normal weight

Table 5. Daily energy and nutritional intake of cases, controls and the total population compared to the recommended daily allowance (RDA)

\begin{tabular}{|l|c|c|c|c|c|}
\hline $\begin{array}{c}\text { Daily energy and } \\
\text { nutritional intake }\end{array}$ & RDA & $\begin{array}{c}\text { Mothers of LBW } \\
\text { newborns }\end{array}$ & $\begin{array}{c}\text { \% RDA for } \\
\text { mothers of LBW } \\
\text { newborns }\end{array}$ & $\begin{array}{c}\text { Mothers of NW } \\
\text { newborns }\end{array}$ & $\begin{array}{c}\text { \% RDA for } \\
\text { mothers of NW } \\
\text { newborns }\end{array}$ \\
\cline { 3 - 6 } & Mean \pm SD & Mean \pm SD & Mean \pm SD & Mean \pm SD \\
\hline Energy $\left(\right.$ Kcal day $\left.^{-1}\right)$ & 2500 & $2721 \pm 1036.96$ & $108.84 \pm 41.47$ & $3118 \pm 860.54$ & $124.72 \pm 34.42$ \\
\hline Iron $\left(m g\right.$ day $\left.^{-1}\right)$ & 27 & $14.14 \pm 7.46$ & $52.37 \pm 27.62$ & $19.11 \pm 9.28$ & $70.77 \pm 34.37$ \\
\hline Folates $\left(\mu\right.$ day $\left.^{-1}\right)$ & 600 & $397 \pm 172.53$ & $66.16 \pm 28.75$ & $436 \pm 183.14$ & $72.66 \pm 30.52$ \\
\hline Protein $\left(\right.$ g day $\left.^{-1}\right)$ & 71 & $94.8 \pm 61.87$ & $133.52 \pm 87.14$ & $108.2 \pm 50.84$ & $152.39 \pm 71.60$ \\
\hline Vitamin $\left(\mathrm{mg} \mathrm{day}^{-1}\right)$ & $80-85 *$ & $89 \pm 77.78$ & $104.70 \pm 91.50$ & $117 \pm 95.45$ & $137.64 \pm 112.29$ \\
\hline Calcium $\left(\mathrm{mg} \mathrm{day}^{-1}\right)$ & 1000 & $338.20 \pm 155.01$ & $33.82 \pm 15.50$ & $60.23 \pm 324.83$ & $60.23 \pm 32.48$ \\
\hline Zinc $\left(\mathrm{mg} \mathrm{day}^{-1}\right)$ & $13-11 *$ & $9.65 \pm 7.24$ & $87.72 \pm 65.81$ & $11.02 \pm 8.36$ & $100.18 \pm 76$ \\
\hline Magnesium $\left(\mathrm{mg} \mathrm{day}^{-1}\right)$ & $400-350 *$ & $487 \pm 295.57$ & $139.14 \pm 84.44$ & $507 \pm 275.77$ & $144.85 \pm 78.79$ \\
\hline
\end{tabular}

*Indicates levels used by pregnant women $\leq 18$ years old and $>18$ years old. SD: standard deviation. §https://ods.od.nih. gov/HealthInformation/Dietary_Reference_Intakes.aspx 
who have reported that there is no relationship between maternal age and fetal growth $[12,5]$. The information concerning the mothers of newborns with an LBW, namely their profession, the associated low monthly income, the low level of education and the rural origin testify to a state of precariousness among this population. This social fragility often at the base of a poor nutritional state of mothers is responsible for LBW [9]. In this study, no significant association was found between LBW and parity. The literature reports primiparity as a protective factor against unfavorable fetal outcomes and in particular against LBW [11], while increased parity has been described as a factor favoring unfavorable pregnancy outcomes in the mother and fetus [19]. Regarding the follow-up of prenatal consultation follow-up, women who do not have any follow-up during pregnancy or who have poor prenatal follow-up are 2.91 times more likely to give birth to newborns with LBW. This finding is consistent with that reported by other research $[7,25]$ affirming that the lack of monitoring of pregnancy does not predict the curable medical causes of LBW or monitor anemia or nutritional deficiencies in mothers. In addition, nutrition education, which is an integral part of prenatal consultation monitoring, is significantly associated with LBW in the present study. Univariate analysis shows that the variables that persist significantly associated with LBW are origin, socioeconomic level, prenatal consultation monitoring and nutritional education. Data from the present study also report strong associations between Apgar score, neonatal resuscitation, and LBW. These factors are important predictors of child survival, responsible in the short term for fetal and neonatal mortality and infant morbidity [20,22]. Of the 344 live newborns studied in this study, the mean weight was $2013.95 \mathrm{~g}$ \pm 372.95 for LBW newborns and $3380 \pm 217.59 \mathrm{~g}$ for NW newborns. This difference in birth weight can be explained by the unfavorable socioeconomic conditions and nutritional situation in LBW[17]. In the sample studied, the newborns were predominantly female with a rate of $60.46 \%$ among the newborns of LBW and $63.95 \%$ of the newborns of normal weight. Data on anthropometric parameters show that with the exception of height and Ponderal index, the weight, head circumference and thoracic perimeter were lower in boys than in girls. Furthermore, the results found in this study show that there is no significant influence of the mother's age on the anthropometric parameters of newborns. On the other hand, the weight, height and BMI of the mother significantly influence the anthropometric measurements of newborns at birth. These data support the hypothesis that the nutritional status of the mother, reflected by body mass index, height and weight in late pregnancy, plays a determining role in fetal growth in newborns of LBW included in this study [1].

The dietary data evaluated with the mothers of the two groups of newborns made it possible to determine the consumption profile of the different food groups. The results obtained show that overall, the diet of all women provides a high consumption of cereals. However, it appears that meats, fish, eggs, dairy products and vegetables are consumed little by mothers of newborns with LBW compared to mothers of newborns of normal weight. A statistically significant association is found between low birth weight and low consumption of meats, eggs, dairy products and vegetables. In addition, this low consumption of food groups, essential for a good evolution of pregnancy, could be explained by the cost of these foods. Several studies in the literature have indeed demonstrated the effect of socio-economic status on the quality of diet $[15,17]$. This diet being poor in fruits and vegetables, meats and dairy products in addition to the high consumption of cereals source of energy could justify the high prevalence of overweight recorded among mothers of newborns with LBW (62.2\%), while the requirements for most nutrients are not covered. These results are in agreement with those of the literature confirming that a good quality diet is correlated with a normal height and weight state [10].

In all the mothers participating in the study, the results reported show that the energy intakes are sufficient to lead a normal pregnancy. They are even higher than those found in other populations [2, 4], probably due to the high consumption of bread among the Moroccan population in general. In addition, the intake of protein, vitamin $\mathrm{C}$ and magnesium are also adequate. However, with the exception of zinc, which only covers the daily intake of mothers of normal weight newborns, mothers of both groups of newborns have deficient intakes of calcium, iron and folates. These deficiencies appear to be more increased in mothers of newborns with LBW whose intakes only cover $33.82 \%$ of the RDA for calcium, $50 \%$ for iron, $66.16 \%$ for folates and $87.72 \%$ for zinc. Inadequate intakes of these nutrients could have a negative impact on the health of the mother-child couple. Indeed, calcium deficiencies are responsible for maternal hypertension and eclampsia attacks [24], and anemia induced by iron, folates and zinc deficiency can generate harmful effects for the mother and increase the risk of preterm delivery and the risk of low birth weight in the newborn $[2,18]$

\section{CONCLUSION}

Recognition of risk factors for LBW may lead to specific recommendations for parturient. Awareness of the importance of a balanced diet for pregnant 
women should therefore be promoted. This must take place during the life cycle, that is, in antenatal consultations but also from childhood, adolescence and adulthood. Indeed, the Sustainable Development Goals for children, such as LBW and wasting, will only be achieved if maternal nutrition is high on the stakeholders' agenda.

If increasing the consumption of zinc and folic acid appears to be a challenge through dietary diversity, supplementation/fortification programs before and during pregnancy should be promoted to avoid these deficiencies.

\section{Acknowledgments}

The authors wish to thank the participants to this study, the staff at the El Jadida Provincial Hospital for their cooperation. The survey was supported by the Moroccan Ministry of Higher Education and Research.

\section{Conflict of interest}

The authors declare that they have no links of interest.

\section{Contributions from the authors}

Houda Elfane: study design, data collection, data analysis and interpretation, manuscript writing. Sanaa El-Jamal: study design, manuscript review. Khadija Sahel: study design, manuscript review. Mohamed Mziwira: critical reading and correction of the manuscript. Mohamed El Ayachi: critical reading and correction of the manuscript. Rekia Belahsen: ensures the scientific validity of the study from concept to drafting of the manuscript.

\section{REFERENCES}

1. Ballon M, Botton J, Charles M, De Lauzon-Guillain B, Carles Forhan A, Heude B, Lioret S.: Study of modifiable mediating factors of the relationship between the level of education of the mother and the weight and height of the mother. Child at birth. J Epidem Publ Health 2019;67:S41-S64; doi.org/10.1016/j.respe.2018.12.034.

2. Belgnaoui $S$, Belahsen R.: Nutrient intake and food consumption among pregnant women from an agricultural region of Morocco. Int J Food Sci Nutr; 2005;00 (0): 1-9; Doi: 10.1080/09637480500465261.

3. Blencowe Hannah et al: National, regional and global estimates of low birth weight in 2015, with trends from 2000: a systematic review. The Lancet Global Health, Volume 7, Number 7, e849 - e860.https://doi.org/10.1016/ $\mathrm{S} 2214-109 \mathrm{X}(18) 30565-5$

4. Boufars A, Belghiti H, Guerinech H, Bouaiti E, Razine $R$, Mrabet $M$.: Energy intake in a population of pregnant women at the Mohamed V military instruction hospital in Rabat, Morocco. J Epidem Publ Health, 2015;63:S85 - S86. Doi: 10.1016/j.respe.2015.03.111.
5. Chiabi A, Mah E, Ntsama Essomba MJ, Nguefack S, Mbonda E, Tchokoteu PF.: Factors associated with the survival of very low birth weight newborns at the gyneco-obstetrics and pediatric hospital in Yaoundé, Cameroon. Pediatric Archives 2014;21(2):142-146. Doi: 10.1016/j.arcped.2013.11.017.

6. Djadou K, Sadzo-Hetsu K, Tatagan-Agbi K, Assimadi K, Sodzi K, Lapillonne A.: Anthropometric parameters, frequency and risk factors of intrauterine growth retardation in full-term infants in North Togo. Pediatric Archives 2005;12:1320-1326.

7. El Hamdani FZ, Vimard P, Baali A, Zouini M, Cherkaoui $M$ : Prenatal care in the city of Marrakech. Med Sante Trop. 2013;23:162-167.

8. Fayyaz J. : Index Ponderal. J Pak Med Assoc 2005 Jun;55(6):228-9. PMID 16045088.

9. Hassoune $S$, Bassel $S$, Nani S, Elbouri H, Zine K, Maaroufi A.: Maternal factors associated with low birth weight: case-control study in a Moroccan public hospital. Pan Afr Med J. 2015;20:303. DOI: 10.11604/ pamj.2015.20.303.2659.

10. Heude B, Jacota M, Forhan A. Charles M.; Weight history of women before and during pregnancy and preand postnatal growth of the child. J Epidem Publ Health, 2014;62:S173. Doi: 10.1016 / j.respe.2014.06.008.

11. Tshinzobe JCK, Ngaya DK.: Etude cas-témoins des facteurs associés à l'insuffisance pondérale à la naissance au Centre Hospitalier de Kingasani, Kinshasa (République Démocratique Congo) [Case-control study of factors associated with low birth weight at the Kingasani Hospital Center, Kinshasa (Democratic Republic of Congo)]. Pan Afr Med J. 2021 Jan 27;38:94. French. doi: 10.11604/pamj.2021.38.94.16099

12. Moyambe JN, Bernard P, Khang'Mate F, Nkoy AM, Mukalenge FC, Makanda D, Twite E, Ndudula AM, Lubamba C, Kadingi AK, Kayomb M, Kayamba PK.: Etude des facteurs de risque du retard de croissance intra-utérin à Lubumbashi [Risk factors for intra-uterine growth retardation in Lubumbashi]. Pan Afr Med J. 2013;14:4. French. doi: 10.11604/pamj.2013.14.4.1798.

13. Luhete PK, Mukuku O, Kayamba PK.: Etude du faible poids de naissance associé à l'âge maternel et la parité dans une population couple mère-enfant suivi à Lubumbashi [Study of low birth weight associated with maternal age and parity in a population of mother and children in Lubumbashi]. Pan Afr Med J. 2015 Mar 16;20:246. French. doi: 10.11604/pamj.2015.20.246.5169

14. Kangulu IB, Ngoy Umba EK, Kabamba Nzaji M, Mwenze Kayamba PK.: Risk factors for low birth weight in semi-rural areas of Kamina, Democratic Republic of Congo. Pan Afr Med J. 2014;17:220 [Doi: 10.11604/ pamj.2014.17.220.2366].

15. Ravaoarisoa L, Rakotonirina J, Andriamiandrisoa D, Humblet P, Rakotomanga JDM.: Habitude alimentaire des mères pendant la grossesse et l'allaitement, région Amoron'i Mania Madagascar: étude qualitative [Women's dietary habits during pregnancy and breastfeeding in Amoron'i Mania region, Madagascar: a qualitative study]. Pan Afr Med J. 2018 Apr 2;29:194. French. doi: 10.11604/pamj.2018.29.194.12873. 
16. Medeiros TKS, Dobre $M$, da Silva DMB, Brateanu $A$, Baltatu OC, Campos LA.: Intrapartum fetal heart rate: a possible predictor of neonatal acidemia and Apgar score. Front Physiol. 2018; 9: 1489. Doi: 10.3389/ fphys.2018.01489.

17. Nakamura A, Melchior M, El-Khourya F.: Maternal socioeconomic situation and low birth weight: the mediating effect of maternal smoking during pregnancy. Analysis of data from the ELFE cohort. Journal of Epidemiology and Public Health 67. 2019; S41-S64. Doi.org/10.1016/j.respe.2018.12.034.

18. Ouzennou N, Tikert K, Belkedim G, Jarhmouti F. Baali A.: Prevalence and social determinants of anemia among pregnant women in the Province of Essaouira, Morocco. Public Health, 2018;5(5):737-745. Doi. org/10.3917/spub.186.0737.

19. Padonou G, Le Port A, Cottrell G, Guerra J, ChoudatI, Rachas A, Bouscaillou J, Massougbodji A, GarciaA, Martin-Prevel $Y$ :: Prematurity, intrauterine growth retardation and low birth weight: risk factors in a malaria-endemic area in southern Benin, Transactions of The Royal Society of Tropical Medicine and Hygiene, 2014 Feb;108(2): 77-83, https://doi.org/10.1093/trstmh/ trt099

20. Ilunga P.M. et al.: Frequency and early neonatal prognosis of low birth weight in Lubumbashi, Democratic Republic of Congo. Pan Afr Med J. 2016;23:232. Doi: 10.11604/pamj.2016.23.232.8287.

21. Ramakrishnan U, Grant F, Goldenberg T, Zongrone $A$, Martorell R.: Effect of women's nutrition before and during early pregnancy on maternal and infant outcomes: a systematic review. Paediatr Perinat Epidemiol. 2012;26 Suppl 1:285-301. Doi: 10.1111/j.13653016.2012.01281.x..

22. The Apgar score. Gynecologists committee on obstetric practice newborn and American college of obstetricians and American academy of pediatrics committee on fetus and pediatrics 2015;136:819; published online, 2015 September 28; Doi: 10.1542 / peds.2015-2651.

23. Thompson FE, Byers T:: Dietary Assessment Resource Manual. J Nutr 1994;124:2245S/ 2317S. Doi: 10.1093/ jn/124.suppl_11.2245s.

24. Touati-Mecheri D, Bensalem A, Oulamara $H$, Abelnacer AA.: Calcemia at childbirth and birth weight. J. Epidem. Publ Health, 2016;64:S251. Doi: 10.1016/ j.respe.2016.06.295.

25. Traore BM, Diallo H, Diarra AS, El fakir S, Nejjari C.: Factors associated with low birth weight in community health center of Yirimadio. Annales des Sciences de la Santé, 2016;1(7):8-15.

26. UNICEF, WHO, the World Bank. 2017. Levels and trends in child malnutrition: UNICEF-WHO-The World Bank joint child malnutrition estimates. ISBN 978-924-000357-6 (electronic version).

27. United Nations Children's Fund and World Health Organization. Low Birthweight: country, regional and global estimates. United Nations Children's Fund and World Health Organization New York. 2004. https:// apps.who.int/iris/handle/10665/43184

28. WHO Expert Committee on Physical Status: the Use and Interpretation of Anthropometry (1993: Geneva, Switzerland) \& World Health Organization (1995) Physical status: the use of and interpretation of anthropometry. Report of a WHO Expert Committee. World Health Organization. Available from: https:// apps.who.int/iris/handle/10665/37003.

Received: 24.09 .2021

Accepted: 25.11.2021

Published online first: 05.12.2021 